\title{
Price Rigidity and Wage Rigidity: Market Failure or Market Efficiency
}

\author{
Chao Chiung Ting ${ }^{1}$ \\ ${ }^{1}$ Graduated from Michigan State University, USA \\ Correspondence: Chao Chiung Ting, Graduated from Michigan State University, $633398^{\text {th }}$ Place 1E, Rego Park, \\ NY 11374, USA. E-mail: tingtch7ti@aol.com
}

Received: September 3, 2017

Accepted: September 25, 2017

Online Published: October 1, 2017

doi:10.5539/ijef.v9n11p82

URL: https://doi.org/10.5539/ijef.v9n11p82

\begin{abstract}
We observe that money wage and price level are not only rigid but also flexible in different business cycles. For example, there are inflationary recessions (e.g., oil crisis in U.S.) versus deflationary recessions (e.g., Great Depression between 1929 and 1933) as well as price rigidity (e.g., Great Depression between 1934 and 1939). Thus, the general price theory, including wage, should explain both price flexibility and price rigidity. When demand curve shifts during business cycle, the best strategy of the firm is to adjust capital and labor (i.e., size of the firm) so as to shift supply curve toward the same direction as demand curve shifts. If both supply curve and demand curve shift toward the same direction proportionally, there is perfect price rigidity. When product price is rigid, the firm is willing to pay previous wage. Thus, price rigidity and wage rigidity are effect (i.e., not only ex-post phenomenon that we observe but also endogenous market efficiency that arises from to the coordination of supply and demand), not exogenous market failure to disturb economy.
\end{abstract}

Keywords: price rigidity, wage rigidity, menu cost, price setting, business cycle, monetary policy, market failure, market efficiency

\section{Introduction}

Economists rely on price rigidity and wage rigidity (i.e., nominal rigidity) to explain both unemployment fluctuation and the effectiveness of monetary policy in the short run (i.e., the slope of short run Phillips curve is negative) while monetary policy is ineffective in the long run due to natural rate unemployment hypothesis (i.e., the slope of long run Phillips curve is vertical). Wage efficiency hypothesis argues that labor productivity will decrease due to low morale if firms reduce wage. Therefore, firms do not reduce wage in recession. Besides, wage of union workers are set to be fixed by collective bargain exogenously. Markets cannot fully adjust prices to restore full employment equilibrium automatically because exogenous wage rigidity leads to price rigidity due to the reason that production cost is fixed by wage rigidity. But there are empirical evidences against wage-price rigidity hypothesis. The union share of labor force was around 8 percent in the beginning of Great Depression and eroded to 6 percent in 1933 as high as boom in 1920s (Note 1). Lucas and Rapping (1969) argued that the number of union labor in U.S. was no more than 25 percent of total labor force, which is too small to cause wage rigidity nationwide. It seems to be impossible that wage rigidity makes Great Recession be the most severe post-war recession because the number of union worker in U.S. declines from 20.1 percent (17.7 million workers) of total labor force in 1983 to 10.7 percent (14.6 million workers) in 2016 (Note 2). The significance of long term contract in U.S. obsoletes. Cole and Ohanian (1999) showed that labor productivity were 100, 95.9, 95.4, 90.7 and 87.9 from 1929 to 1933 in table 6, attached in appendix B. Lucas (1972) listed money wage rate between 1929 and 1933 in table 1 , attached in appendix A, that were $.56, .56, .53, .48$ and .46 . According to wage efficiency hypothesis, wage rigidity and decrease in labor productivity in 1930 could not coexist. Wage efficiency hypothesis also cannot explain why firms intended to reduce wage in order to reduce labor productivity from 1931 to 1933 . Besides, Bonoetial (2015) reported that both wage and price were flexible in Great Depression. Price level fell 25 percent and wage in manufacturing also declined about 20 percent from 1929 to 1933. Phillips (1958) not only worked out Phillips curve but also studied the recession from 1925 to 1929 in British and concluded in page 295 "Thus the evidence does not support the views, which is sometimes expressed, that policy of forcing the price level down failed because of increased resistance to downward movement of wage rate." Besides, wage increased from 1934 to 1939 during Great Depression while price level 
was rigid in Lucas' table 1. It implies that increase in wage does not accelerate inflation rate so that the relationship between wage and price level is random in macroeconomics (e.g., wage rigidity may not cause price rigidity). In summary, neither nominal wage rigidity nor the argument that nominal wage rigidity causes price rigidity is supported by empirically evidences.

Instead of wage rigidity, New Keynesian economics explains price rigidity by price setting and menu cost. If Calvo (1983), Akerlof and Yellen (1985), Blanchard and Kiyotabi (1986), and Mankiw (1986) are all correct, price setting and menu cost should prevent prices from falling during recession as well as rising during boom in real world. It implies that there is no pro-cyclical co-movement of price level and aggregate income. But pro-cyclical co-movement is an essential feature of business cycle. Further, Rothbard (2002, pp. 101-103) reported that price level declined 42 percent and real GNP grew 16 percent between 1839 and 1843. Neely (2011) found that output grew exceed 7.6 percent per year and price level fell averagely almost 5 percent per year from 1876 to 1879 . Bordo et al. (2004) studied the deflationary growth at the end of nineteenth century in U.S., U.K. and Germany. Since the relation between aggregate income and price level usually is positive (i.e. pro-cyclical co-movement), there was deflationary growth versus inflationary growth. We also observed inflationary recession (e.g., two oil crises in U.S.) versus deflationary recession. Besides, there was price rigidity (e.g., between 1935 and 1939 in Great Depression). Thus, the relationship between price level and aggregate income would be random walk rather than rigidity in time series. If price setting and menu cost is the general price theory, price setting and menu cost should explain (1) positive relation between price level and nominal aggregate income, (2) negative relation between price level and real aggregate income, and (3) price rigidity. For example, price setting and menu cost is supposed to explain both deflationary depression (1929-1933) and price rigidity in long recovery (1934-1939) during Great Depression. But price setting and menu cost never discussed (1) and (2). Besides, Bunn and Ellis (2012) found that microeconomic data are inconsistent with any price setting theory in U.K.

Price setting and menu cost hypothesis assumes that there is a probability distribution that firms receive signals of change in price. If supply is equal to demand, then frequency of receiving signal of change in price is zero and duration of change in price is long because there is no incentive for firms to reset price under equilibrium even there is no menu cost. Thus, there is no such probability distribution to emit price signal when economy reaches equilibrium. Consider a case that price and quantity deviate from equilibrium frequently and restore equilibrium automatically while both supply curve and demand curve are given. In this case, average price is sticky but frequency of change in market price is high and duration of change in market price is short. Thus, sticky average price may reflect the situation that supply curve and demand curve are stable instead of market failure and price rigidity while high frequency of change in price and short duration of market price do not indicate business cycle and price flexibility responding to changes in supply and demand. If either supply curve or demand curve shifts, the change in average price is permanent. The permanent change in average price indicates that probability distribution shifts because average price is the mean of probability distribution. Thus, the assumption that frequency of price change signal is given in price setting and menu cost hypothesis is identical to the idea that price probability distribution is given (i.e., price deviates from and converges to equilibrium under the circumstance that both supply curve and demand curve are given) because frequency of a particular price changes when probability distribution shifts. Since price setting and menu cost hypothesis does not concern shifting in supply curve and demand curve so that price is not fully flexible in price setting and menu cost hypothesis, price setting and menu cost hypothesis is equivalent to exogenous market failure.

Gagnon (2007), Barros et al. (2009) and Alvarez (2015) compared frequency, duration and size of price change in low inflation with in high inflation. They all found high frequency, short duration and large size of price change in high inflation and low frequency, long duration and small size of price change in low inflation. Although inflation means that price rises while quantity does not increase, inflation does not imply market failure but suggests that supply curve shift upward more than demand curve so that price level increases and quantity of output decreases under market efficiency. These three papers prove that prices respond to shifting in supply curves and demand curves in variable environment (e.g., high inflation) well while low inflation suggests that economy is stable so that low frequency and long duration of change in price do not imply market failure. Thus, it is my personal interpretation that these three papers not only reject the idea that the combination of low frequency and long duration of change in price implies that price setting and menu cost hypothesis (i.e., market failure) leads to price rigidity but also support the statement that supply and demand determines price efficiently in both variable environment and stable environment.

In summary, market failure is introduced into macroeconomics as exogenous variable to explain nominal rigidity and effectiveness of monetary policy in the short run without empirical evidence so that I interpret Phillip (1958) 
and Bonoetial (2015) to be allusion that wage rigidity and price rigidity are supposed to be ex-post phenomenon endogenously derived from supply and demand.

Ting (2012) argued that borrowing and lending causes the pro-cyclical co-movement of price level, aggregate income, wage, employment and interest rate under full flexibility of price and quantity. Full flexibility of price and quantity has two meanings. First, price and quantity deviate from and converge to equilibrium without restriction while both supply curve and demand curve are fixed. In microeconomics, decrease in price leads to increase in demand (i.e., quantity moves along a given demand curve) because other things are equal (i.e., both demand curve and supply curve are fixed). Price substitution effect drives economists to believe that wage rigidity and price rigidity stop the automatic equilibrium restoration mechanism (i.e., demand for product increases if price falls so that aggregate demand will increase if price level falls). Since price substitution effect is contrary to deflationary recession (i.e., aggregate income and price level fall simultaneously), price substitution effect cannot explain business cycle. It is worth noting that I do not discuss income effect and output effect in this paragraph because income (output) effect drives demand (supply) curve to shift in two dimensions (price and quantity) diagram.

Second, price and quantity change when supply curve and demand curve shift. When supply curve shifts rightward, it is possible that previous equilibrium price is higher than current equilibrium price but previous equilibrium quantity is less than current equilibrium quantity (i.e., the negative relation between price level and aggregate income, e.g., deflationary growth). Inflationary growth appears if demand curve shift rightward (i.e., positive relation between price level and aggregate income, e.g., pro-cyclical co-movement). We have inflationary recession if supply curve shifts upward (e.g., oil crises). Thus, shifting in supply curve and demand curve can make the relationship between price level and aggregate income become random in time series. In macroeconomics, other things are not equal (e.g., aggregate income, unemployment and personal income fluctuate) so that both demand curve and supply curve shift freely. It is possible that price is perfectly rigid downward or upward if both supply curve and demand curve shift toward the same direction proportionally. Thus, perfect price rigidity is a special case of shifting in both supply curve and demand curve. Since shifting in supply curve and demand curve explains not only upward and downward price rigidity but also the random walk relationship between price level and aggregate income in time series, I conclude that shifting in both supply curve and demand curve is the general price theory to explain both nominal rigidity and nominal flexibility in both microeconomics and macroeconomics.

Ting (2010) demonstrated that the growth of the firm is analogous to the growth of economy. It implies a methodology to study economic activity that microeconomic phenomenon is analogous to macroeconomic phenomenon if all individual economic agents react to impact unanimously. In other words, nationwide nominal rigidity exists if we can derive nominal rigidity from firm theory in microeconomics. Ting (2010) substituted maximum return rate on capital for maximum profit to study firm theory because entrepreneurs can manipulate size of the firm in both short run (e.g., capital utilization, lay-off and overtime) and long run. Since size of the firm is determined by capital and labor, change in size of the firm is identical to shifting in supply curve. The objective of this paper is to demonstrate that both nationwide nominal rigidity and nationwide nominal flexibility in the sense of macroeconomics are derived from maximum return rate on capital hypothesis in the sense of microeconomics. In section 2, maximum return rate on capital implies that firms shrink the size (i.e., supply curve shifts leftward) if product demand curve shifts leftward and firms expand size during recovery and boom. Thus, supply curve always shift toward the same direction which demand curve shifts toward in business cycle so that nationwide price rigidity is possible to appear. It proves that price rigidity is ex-post phenomenon to reflect market efficiency, not market failure. It is crucial that observations of sticky price would be empirical evidences to support that supply curve and demand curve shift toward the same direction (i.e., empirical evidence to support market efficiency) rather than empirical evidence of market failure.

In section 3, I will argue that wage is paid by marginal value of labor's marginal product under maximum return rate on capital hypothesis so that wage depends on marginal product of labor and marginal revenue of product. Since the change in product price affects marginal revenue of product, wage is rigid if product price is rigid and wage is flexible if product price is flexible. Money wage fluctuation and money wage rigidity in Great Depression is explained by change in price level and labor productivity successfully in section 4 . Section 5 remarks conclusion.

\section{Price Rigidity}

Economists usually use horizontal supply curve to explain price rigidity. Since horizontal supply curve is a special case for production of the firm, economists fail to construct a general theory of price rigidity on supply 
and demand. Economists ignored the possibility that price is rigid because firms adjust supply curve in order to respond to shifting in demand curve due to changes in aggregate demand in business cycle. In other words, the position of supply curve depends on the position of demand curve in a two dimensions diagram (price and quantity) under the circumstance of business cycle. Note that I do not concern that firms adjust supply curve due to technology progress in this paper. Entrepreneurs may respond to excess demand by expanding production capacity (i.e., supply curve shifts rightward) through investment or overtime working. When glut happens, entrepreneurs may close factory or lay off worker (i.e., supply curve shifts leftward). That is, entrepreneurs can shift supply curves by the manipulation of capital utilization rate and the number of employee in the short run. Thus, the central issue of price rigidity is to construct a microeconomic model in which both supply curve and demand curve always shift toward the same direction to generate different degree of price rigidity when entrepreneurs respond to shifting in demand curve. In other words, I have to prove that shifting in supply curve is more profitable than changing in price and quantity along the given supply curve when demand curve shifts.

When we study cost function of the firm, cost function changes as the firm expands (e.g., changes in short run average cost and envelope theorem in microeconomics) due to increase returns to scale. Thus, if there is equilibrium, then the firm is on optimal size. In microeconomics, firms pursue maximum profit while the size of the firm is given (i.e., given the fixed capital and number of labor). Maximum profit does not describe firm's behavior in business cycle accurately because firms have idle capital and labor during recession due to decrease in demand for product, which implies that the size of the firm is too big to be optimal. Conversely, the size of the firm is too small to be optimal in boom.

Ting (2010) substituted maximum return rate on capital hypothesis for maximum profit hypothesis in order to study firm's behavior under flexible size because increase in absolute amount of profit may lead to decrease in return rate on capital and decrease in absolute amount of profit may drive return rate on capital to rise. Assume that capital and labor are input for production and the firm does not borrow. Maximum return rate on capital means:

$$
\operatorname{Max} \frac{(P-c) Q(K, N)-w N}{K}
$$

Since the firm does not borrow, profit is equal to $P Q(K, N)-w N$ where $N, K$ and $w$ represent labor, capital, and wage respectively. $Q(K, N)$ is production function, in which capital and labor are input. $w N$ is production cost due to the assumption of non intermediate goods. When price is given, the quantity that market demands $(Q)$ will be produced by $Q(K, N)$ so that I replace $Q$ by $Q(K, N) . P Q(K, N)$ is demand curve, which is also suitable for economy as a whole like growth theory. I use $P-c$ and $P-c^{*}$, where $c$ and $c^{*}$ are constant and $c^{*}>c$, to represent two demand curves which are parallel. $(P-c) Q(K, N)$ is located at the rightward of $\left(P-c^{*}\right) Q(K, N)$. The optimal volume of capital and number of employee are:

$$
\begin{gathered}
K=\frac{(P-c) Q-w N}{\left[(P-c)+Q \frac{\partial P}{\partial Q}\right] \frac{\partial Q}{\partial K}}=\frac{(P-c) Q-w N}{(P-c)\left(1+\frac{1}{\eta}\right) \frac{\partial Q}{\partial K}} \\
N=Q \frac{\partial P}{\partial Q} \frac{\partial Q}{\partial N} \frac{\partial N}{\partial w}+(P-c) \frac{\partial Q}{\partial N} \frac{\partial N}{\partial w}-w \frac{\partial N}{\partial w}=\left[(P-c)\left(1+\frac{1}{\eta}\right) \frac{\partial Q}{\partial N}-w\right] \frac{\partial N}{\partial w} \\
\frac{\partial K}{\partial c}=\frac{-Q\left[(P-c)+\frac{\partial P}{\partial Q}\right] \frac{\partial Q}{\partial K}-\left(-\frac{\partial Q}{\partial K}\right)[(P-c) Q-w N]}{\left\{\left[(P-c)+Q \frac{\partial P}{\partial Q}\right] \frac{\partial Q}{\partial K}\right\}^{2}}=\frac{-Q\left[(P-c)+\frac{\partial P}{\partial Q} Q\right] \frac{\partial Q}{\partial K}-\left(-\frac{\partial Q}{\partial K}\right) K\left[(P-c)+\frac{\partial P}{\partial Q} Q\right] \frac{\partial Q}{\partial K}}{\left\{\left[(P-c)+\frac{\partial P}{\partial Q} Q\right] \frac{\partial Q}{\partial K}\right\}^{2}}=\frac{K \frac{\partial Q}{\partial K}-Q}{\left[(P-c)+\frac{\partial P}{\partial Q}\right] \frac{\partial Q}{\partial K}}<0
\end{gathered}
$$

Equation (2) means that marginal value of marginal product of capital is equal to profit divided by capital (i.e., return rate on capital). When $\eta>-1$ (e.g., -0.5$), 1+\frac{1}{\eta}<0$ (i.e., marginal revenue is negative). It means that total revenue will decline while firms increase expenditure on production (i.e., increase volume of output). It implies that profit declines. Thus, firms will not move along supply curve when $\eta>-1$ but firms will keep shifting supply curve leftward until $\eta<-1$ and then firms determine the optimal volume of capital. For example, firms shift supply curve leftward as much as possible if demand curve is vertical (i.e., price elasticity of demand is equal to zero) and demand curve shifts leftward or rightward because the profit arising from shifting in supply curve is greater than the profit yielding from moving along a given supply curve (i.e., firms can sell the same volume of output with higher price if supply curve can move leftward and demand curve is vertical). Thus, if $\eta>-1$, the solution of optimal volume of capital is the minimum size of the firm. Similarly, the solution for 
the volume of optimal capital is zero when $P Q-w N \leq 0$ because firms are not worth existing if firms are deficit.

Equation (3) is the optimal number of workers that the firm plans to employ (i.e., labor demand). Labor demand depends on marginal value of marginal product of labor so that labor demand curve shifts if product demand curve shifts (e.g., $P-c$ and $P-c^{*}$ ). In equation (2), $c$ is income effect, arising from change in aggregate income and personal income, on demand for output. In equation (3), $c$ is output effect, arising from shifting in supply curve, on labor demand when product demand curve shifts leftward from $P Q$ to $(P-c) Q$.

Equation (4) demonstrates that the relationship between the optimal volume of capital and the constant $c$, which represents shifting in demand curve, is negative due to the reason $Q=\frac{\partial Q}{\partial K} K+\frac{\partial Q}{\partial N} N$ and $1+\frac{1}{\eta}>0$. Thus, the firm always shifts supply curve and labor demand curve toward the same direction as demand curve shifts toward. In other words, if demand curve of product shifts, the best strategy for entrepreneurs is to adjust the size of the firm whether market is perfect competition or imperfect competition. The degree of price rigidity depends on production function and demand curve. Note that demand curve is influenced by market structure, e.g., demand curve is horizontal in perfect competition and demand curve in imperfect competition may be kink.

It is worth noting that we do not know that market is in excess demand or excess supply after both supply curve and demand curve shift toward the same direction. If both supply curve and demand curve shift leftward but market is in excess demand, there is recovery. Conversely, recession happens.

\section{Wage Rigidity}

Price and quantity should be derived from in the same model because price and quantity are inseparable from the view point of supply and demand. Wage should be derived from the model from which we derive employment. Thus, we have to understand fluctuation of employment in business cycle when we discuss fluctuation of wage in business cycle. Certainly, unemployment exists because market wage is higher than equilibrium wage. In Classical school, the problem of unemployment is the deviation away from equilibrium in labor market while both labor demand curve and labor supply curve are given. To lower money wage is the only way to reduce unemployment under this circumstance. In Classical school, the relationship between unemployment and wage is positive due to substitution effect. But we observed that unemployment increased while wage fell or did not rise in depressions (i.e., the relationship between unemployment and wage is negative e.g., Phillips curve). Thus, we have to reject the unemployment theory of Classical school because we cannot derive the conclusion that wage does not rise but the volume of unemployment increases from the assumption that both labor demand curve and labor supply curve are given. In other words, we have to use shifting in labor demand curve and labor supply curve to handle the unemployment problem in business cycle.

For example, we observe both unemployment and population grow in underdeveloped countries. Following Classical school, economists are supposed to recommend wage cutting to take care of unemployment problem in underdeveloped countries. But we observed that underdeveloped countries in East Asia promoted both foreign investment and export so that the rightward shifting in labor demand curve, caused by foreign investment and export (i.e., impact arising from rightward shifting in product demand curve on labor demand in equation (3) due to the difference between $c$ and $c^{*}$ ), is farther than the rightward shifting in labor supply curve due to population growth. Thus, wage and unemployment had been correlated negatively in East Asia countries for the second half of twentieth century so that we cannot attribute increase in unemployment to high wage in business cycle entirely. That is, output effect dominates wage substitution effect so that labor demand overcomes labor supply to determine wage and unemployment in East Asia. I conclude that economists should derive wage theory from the model that economists developed employment theory (i.e., employment theory of labor demand) based on aggregate income in the sense of macroeconomics and demand for labor for the purpose of production (e.g., labor demand under maximum return rate on capital hypothesis) in the sense of microeconomics.

If unemployment increases due to job searching, government is unnecessary to take care of unemployment problem during recession because it will not enhance welfare of job searchers. Since job searchers look for higher wage than before (i.e., labor supply curve shifts leftward), job searching hypothesis should predict that wage rises during recession instead of wage rigidity and decrease in wage. Besides, job searching hypothesis predicts that the number of vacancy should increase while aggregate income declines because job searchers quit. But Hall (2005) found two facts against job search hypothesis. Fist, unemployment rises because people are hard 
to find job. In other words, the number of vacancy decreases relatively to the number of people who need a job during recession. Second, unemployment is not interfered by job searching. I explain this phenomenon by the hypothesis that job searchers would find new job before they quit rather than job searchers quit job before they find new job so that searching for a better job is different from finding a job to make living while cyclical unemployment is to find a job for making living. Of course, aggregate income will fall when labor supply decreases because labor input is less than before. When economist use job search to explain decrease in aggregate income, economists ignore the critical shortcoming of job search hypothesis in macroeconomics that job search hypothesis cannot create glut in output sector because job searchers quit job but still consume so that leftward shifting in aggregate supply curve is supposed to be farther than leftward shifting in aggregate demand curve (i.e., output markets are in excess demand). But there is recession if and only if there is glut in output sector. It is crucial that I conclude the decrease in aggregate income caused by job searching is not recession (i.e., not excess supply of goods). Similarly, if labors substitute present leisure for present work (i.e., labor supply curve shifts leftward because some labors withdraw from labor market voluntarily in order to enjoy leisure), aggregate income will fall but unemployment may not increase and glut may not appear. This conclusion is also against the fact that wage does not rise, glut emerges (i.e., aggregate income falls) and unemployment increases in recession simultaneously.

Economists assumed that short run labor supply curve is horizontal because they believed that wage rigidity is the situation in which labor demand curve shifts rightward or leftward while the horizontal labor supply curve is given. If labor demand curve is given so that the section of the horizontal labor supply curve beyond labor demand curve implies unemployment, then excess supply of labor will drive the horizontal labor supply curve downward continuously until labor market reaches full employment. Thus, horizontal labor supply curve does not guarantee that wage is rigid. Of course, economists can introduce long term contract into the model so that the horizontal labor supply curve resists downward shifting. But Lucas and Rapping (1969) denied the possibility that long term contract is capable to explain nationwide wage rigidity because the largest number of union workers in US history is around 25 percent of total workers, which is too small to spread wage rigidity nationwide.

In summary, labor demand is corner stone of wage and employment theory instead of labor supply (e.g., Lucas and Rapping (1969) believed that labor supply is corner stone) so that the model, which I will derive wage from, is the same model that I derived labor demand from because both decrease in labor supply (e.g., job searching) and horizontal labor supply curve cannot explain why wage is not only rigid but also flexible during recession while glut appears, aggregate income falls and volume of unemployment increases simultaneously. Note that in Table 1 of Lucas (1972), wage was rigid between 1929 and 1930 but wage declined continuously between 1931 and 1933 as well as wage rose continuously between 1934 and 1939 in Great Depression so that the general theory of wage should explain not only wage rigidity but also wage fluctuation.

Aggregate labor demand is derived demand in Ting (2012), which is derived from aggregate income because aggregate income is the value of total output produced in current period. Ting's employment theory is consistent with business cycle because Ting (2012) showed that output sector is in excess supply (i.e., glut) and input sector is in excess supply (i.e., unemployment will increase and wage will not rise) simultaneously in recession as well as output sector is in excess demand and input sector is in excess demand simultaneously in boom. That is, change in aggregate income shifts firm's product demand curves in the sense of microeconomics so that firm's labor demand curve shifts. Labor demand that is derived from maximum return rate on capital hypothesis (equation (3)) is also derived from production. As Ting (2010) predicted that growth in macroeconomics and growth of the firm in microeconomics are analogous, the theory of employment and wage in macroeconomics and the theory of employment and wage in microeconomics are analogous in this paper because labor demand is derived from production in both macroeconomics and microeconomics so that labor demand in the sense of macroeconomics and labor demand in the sense of microeconomics are analogous.

Since unemployment implies that labor supply is greater than labor demand, the wage asked by labors makes no sense when labor market is in excess supply. Thus, the key factor to determine market wage is how much compensation that firms are willing to pay and afford to pay under optimal size of the firm, which is consistent with the conclusion above that labor demand is the key factor to determine change in the volume of employment and wage in macroeconomics. The wage that firms are willing to pay under maximum return rate on capital hypothesis is:

$$
w=\left[Q \frac{\partial P}{\partial Q}+(P-c)\right] \frac{\partial Q}{\partial N}-N \frac{\partial w}{\partial N}=(P-c)\left(1+\frac{1}{\eta}\right) \frac{\partial Q}{\partial N}-N \frac{\partial w}{\partial N}
$$


Equation (5) means that wage depends on marginal value of labor's marginal product. Firms reduce (raise) wage when product demand curve shifts leftward (rightward). It implies that wage in boom is higher than wage in recession because $P-c$ is greater than $P-c^{*}$. Thus, wage fluctuation corresponds to aggregate income fluctuation (i.e., wage, employment and aggregate income are pro-cyclical co-movement in Ting (2012)). Notice that optimal wage becomes negative when $\eta>-1$ because marginal value of marginal product of labor is negative (i.e., marginal revenues is negative). If market product price is fixed due to the reason that both product demand curve and product supply curve shift leftward proportionally, price elasticity decreases because the slope of product demand curve, $(\partial P / \partial Q)$, does not change but the ratio of quantity to price decreases due to decrease in quantity of output and fixed market product price. Moreover, firms usually shut down the most inefficient factory and lay off the most inefficient labor first. Consequently, marginal product of labor rises when product supply curve shift leftward. Thus, equation (5) suggests that firms are willing to and affordable to pay previously market wage while labor demand curve shifts leftward (e.g., recession in the sense of macroeconomics) and market product price is fixed. When shifting in labor demand curve is caused by shifting in product demand curve, market wage is flexible if market product price is flexible and market wage is rigid if market product price is rigid. I propose to name the wage rigidity derived from the maximum return rate on capital as market wage rigidity because maximum return rate on capital hypothesis is equivalent to the analysis of supply and demand, which is different from the wage rigidity arising from government interference by minimum wage law and collective bargain between union labor and firms. Market wage rigidity is the reason why we observed nationwide wage rigidity.

When demand for product decreases continuously but variable cost is lower than marginal revenue, firms would continue to produce rather than close whole factory completely. It implies that firms cannot shift supply curve leftward unconditionally. Sooner or later, firms must respond to excess supply by moving along given supply curve to reduce price and quantity of output instead of shrinking production scale and keeping product price stable. In other words, the market status becomes the fixed product supply curve (i.e., fixed size of the firm) and the leftward shifting product demand curve instead of proportional shifting in product supply curve and product demand curve. Consequently, both market product price and market wage must fall in recession. Changes in size of the firm imply that both price rigidity and wage rigidity occur in the beginning of recession and both flexible price and flexible wage appear in the latter phase of recession.

It is worth noting that decrease (increase) in prices of intermediate goods also shifts supply curve rightward (leftward) because cost decreases (increases). In this case, output prices under the circumstance of shifting in supply curve due to both shifting in demand curve and price changes in intermediate goods are unusually low or high, e.g., oil crisis.

\section{Case Study: Great Depression}

Lucas (1972) listed unemployment rate, money wage rate and price level deflator during Great Depression in Table 1. From 1929 to 1934 , Lucas listed $(.03, .56, .51),(.09, .56, .49),(.16, .53, .45),(.24, .48, .40)$, $(.25, .46, .39)$ and $(.22, .51, .42)$. Since product price did not decline much (i.e., value of marginal product decreased a little) in 1930, money wage rate was rigid while unemployment rate ascended from 3 percent to 9 percent. It implies that firms shrank size in 1930. From 1931 to 1933, the greater price level declined, the greater money wage rate fell. In 1934, price level rose due to recovery so that money wage rate increased. Notice that wage rigidity appeared before wage fluctuation.

The relation between money wage rate and price level changed between 1935 and 1939. Lucas listed $(.20, .52, .43),(.17, .53, .43),(14, .57, .44),(.19, .58, .44)$ and $(.17, .58, .43)$. Price level was fixed but money wage rate rose. Equation (5) predicts that marginal product of labor must rise during those five years. Otherwise, maximum return rate on capital hypothesis is false. This prediction coincides with increase in labor productivity between 1934 and 1939 (96.7, 98.4, 101.6, 100.7, 102.4, 104.6) listed in table 6 of Coley and Ohanian (1999). Labor productivity jumped from 87.9 in 1933 to 96.7 in 1934, which explains why change in money wage rate is greater than change in price level in 1934. This puzzle was emphasized by Lucas and Rapping (1969). In addition, Coley and Ohanian also reported increase in investment between 1934 and 1939, which is helpful to explain price rigidity between 1935 and 1939 because supply curve shifts rightward when the firm invests.

It is worth noting that Coley and Ohanian emphasized the volume of capital may be overestimated from 1930 to 1933 because capital utilization rate was low so that productivity of labor may be underestimated. From 1929 to 1933 , labor productivity indexes were $100,95.9,95.4,90.7$ and 87.9. Changes in money wage rate during these five years were much less than equation (5) predicts because decrease in money wage rate was less than change in price level plus decrease in labor productivity. Underestimation of labor productivity explains this puzzle. But 
Coley and Ohanian omitted that huge increase in investment may also lead to overestimate capital stock because investment does not imply that extra capital is ready to produce. For example, the firm constructs new buildings for factory but does not install equipment yet. Thus, capital may be overestimated and labor productivity may be underestimated after 1934, either. It is helpful to explain increase in wage by increase in labor productivity under price rigidity between 1934 and 1939, especially 1937.

\section{Conclusions}

Since this paper shows that both price rigidity and wage rigidity are ex-post phenomenon (i.e., effect) derived from shifting in supply curve and demand curve (cause) under maximum return rate on capital hypothesis, economists cannot rely on exogenous nominal rigidities to explain why monetary policy affects real aggregate income in the short run (e.g., Phillips curve) anymore. This conclusion is consistent with Ting (2012) which not only predicted that monetary shock does not cause business cycle but also demonstrated that borrowing and lending causes business cycle and pro-cyclical co-movement of price level, wage rate and employment rate (i.e., short run Phillips curve) without nominal rigidity assumption. Since monetary shock cannot cause business cycle by itself, it implies that quantity of money stock cannot affect aggregate income of the economy in which there is no borrowing and lending.

Monetary policy usually affects real aggregate income because monetary policy influences on volume of borrowing and lending due to the reason that money and credit are substitute and Federal Reserve Bank pegs interest rate while interest rate is the price of borrowing and lending. When monetary policy cannot influence on borrowing and lending, monetary policy is ineffective in the short run even there are market wage rigidity and market price rigidity. For example, banks would hoard excess reserve rather than lend to economic agent and firms did not borrow for investment after 2008 so that monetary policy has not worked effectively since 2008 although Federal Reserve Bank expanded monetary base by Quantitative Easing. In addition, Ting (2017) proved that quantity theory of money is false logically as well as the definition of money (e.g., M1 and M2) is false because bank deposit is credit so that there is credit policy instead of monetary policy virtually and actually.

Finally, this paper shows that wage rigidity depends on price rigidity but economists usually argue that wage rigidity leads to price rigidity in macroeconomics.

\section{References}

Akerlof, G. A., \& Yellen, J. L. (1985).A Near-Rational Model of the Business Cycle with Wage and Price Inertia.Quarterly Journal of Economics, 100, 823-838. https://doi.org/10.1093/qje/100.Supplement.823

Alvarez, F., Beraja, M., Gonzalez-Rozada, M., \& Neameyer, A. (2011).From Hyperinflation to Stable Prices: Argentina's Evidence on Menu Cost Models. Working Paper University of Chicago.

Barros, R., Bonomo, M., Carvalho, C., \& Matos, S. (2009). Price Setting in a Variable Macroeconomic Environment: Evidence from Brazilian CPI. Working Paper Pontf.University, Rio de Jameiro.

Blanchard, O. J., \& Kiyotaki, N. (1987). Monopolistic Competition and the Effects of Aggregate Deamd. American Economic Review, 77, 647-666.

Bordo, M. D., Lane, J. L., \& Redlish, A. (2004). Good versus Bad Deflation: Lesson from the Gold Standard Era. NBER working paper No. 10329.https://doi.org/10.3386/w10329

Borio, C., Erdem, M., Filrardo, A., \& Hofman, B. (2015). The cost of Deflation: A historical perspective. Quarterly Review, Bank of International Settlement.

Calvo, G. (1983). Staggered Prices in a Utility Maximizing Framework. Journal of Monetary Economics, 12, 383-398. https://doi.org/10.1016/0304-3932(83)90060-0

Cole, H. L., \& Ohanian, L. E. (1999). The Great Depression in the United States. From a Neoclassical Perspective. Quarterly Review, Federal Reserve Bank Minneapolis, 23, 2-24.

Gagnon, E. (2009). Price Setting Under Low and High Inflation: Evidence from Mexico. Quarterly Journal of Economics, 124, 1221-1263. https://doi.org/10.1162/qjec.2009.124.3.1221

Hall, R. E. (2005). Job Loss, Job Finding and Unemployment in the U.S. Economy Overthe Past Fifty Years. NBER Working Paper, No. 11678.

Lucas, R. E. (1972). Unemployment in the Great Depression: Is There a Full Explanation. Journal of Political Economy, 80, 186-191. https://doi.org/10.1086/259872

Lucas, R. E., \& Rapping, L. A. (1969). Real Wages, Employment, and Inflation. Journal of Political Economy, 77, 721-54. https://doi.org/10.1086/259559 
Mankiw, G. N. (1986). Small Menu Costs and Large Business Cycles: A Macroeconomic Model of Monopoly. Quarterly Journal of Economics, 100, 529-537. https://doi.org/10.2307/1885395

Neely, C. J. (2010). U. S. History Experience with Deflation. Economic Synopses, Federal Reserve Bank, St. Louis.

Phillips, W. A. (1958). The Relation between Unemployment and the Rate of Change of Money Wage Rates in United kingdom, 1861-1957. Economica, 25, 283-299.

Rothbard, M. N. (2002). History of Money and Banking in the United States: The Colonial Era to World War II. Edited with an Introduction by Joseph T. Salrno, Ludwig Von Mises Institute.

Ting, C. C. (2010). The Optimal Size of the Firm and Growth Theory. European Journal of Economics Finance and Administrative Science, 25, 25-28.

Ting, C. C. (2012). The True Cause of Business Cycle. European Journal of Business and Economics, 4, 47-51.

Ting, C. C. (2017). Quantity Theory of Money: True or False. International Journal of Economics and Finance, 9(10), 46-63. https://doi.org/10.5539/ijef.v9n10p46

\section{Appendix A. Table 1 in Lucas (1972)}

Table 1. Wages and Prices during the Depression

\begin{tabular}{cccccc}
\hline Year & $\begin{array}{c}\text { Unemployment } \\
\text { Rate } U_{t}\end{array}$ & $\begin{array}{c}\text { Money Wage } \\
\text { Rate } W_{t}(\$)\end{array}$ & $\begin{array}{c}\text { "Normal" Money } \\
\text { Wage Rate } W_{t}^{*}(\$)\end{array}$ & $\begin{array}{c}\text { GNP Deflator } p_{t}(1958=1) \\
\text { "Normal" GNP } \\
\text { Deflator } p_{t}^{*}\end{array}$ \\
\hline 1928 & .04 & .55 & .56 & .50 & .51 \\
1929 & .03 & .56 & .57 & .51 & .51 \\
1930 & .09 & .56 & .58 & .49 & .50 \\
1931 & .16 & .53 & .57 & .45 & .48 \\
1932 & .24 & .48 & .55 & .40 & .45 \\
1933 & .25 & .46 & .52 & .39 & .43 \\
1934 & .22 & .51 & .53 & .42 & .43 \\
1935 & .20 & .52 & .53 & .43 & .43 \\
1936 & .17 & .53 & .54 & .43 & .43 \\
1937 & .14 & .57 & .56 & .44 & .44 \\
1938 & .19 & .58 & .57 & .44 & .44 \\
1939 & .17 & .58 & .59 & .43 & .44 \\
1940 & .15 & .60 & .60 & .44 & .44 \\
1941 & .10 & .66 & .63 & .47 & .45 \\
1942 & .05 & .76 & .68 & .53 & .48 \\
1943 & .02 & .84 & .75 & .57 & .51 \\
1944 & .01 & .90 & .81 & .58 & .54 \\
1945 & .02 & .98 & .88 & .60 & .56 \\
\hline
\end{tabular}

\section{Appendix B. Table 6 in Cole and Ohanian (1999)}

Table 6. Detrended measures of productivity index, 1929=100

\begin{tabular}{lcc}
\hline Year & Labor Productivity & TotalFactor Productivity \\
\hline 1930 & 95.9 & 94.8 \\
1931 & 95.4 & 93.5 \\
1932 & 90.7 & 87.8 \\
1933 & 87.9 & 85.9 \\
1934 & 96.7 & 92.6 \\
1935 & 98.4 & 96.6 \\
1936 & 101.6 & 99.9 \\
1937 & 100.7 & 100.5 \\
1938 & 102.4 & 100.3 \\
1939 & 104.6 & 103.1 \\
\hline
\end{tabular}




\section{Notes}

Note 1. Reynolds, M. O. (July 17, 2009). A History of Labor Unions from Colonial Times to 2009. Mises Daily News. https://mises.org/library/history-labor-unions-colonial-times-2009

Note 2. Bureau of Labor Statistics, Economic Release, US DL-17-0107. https://bls.gov/news.release/union2.nro.htm

\section{Copyrights}

Copyright for this article is retained by the author(s), with first publication rights granted to the journal.

This is an open-access article distributed under the terms and conditions of the Creative Commons Attribution license (http://creativecommons.org/licenses/by/4.0/). 